\author{
D. Kasymov ${ }^{1,2}$, O. Galtseva ${ }^{3}$ \\ ${ }^{I}$ Tomsk State University, Russia; \\ ${ }^{2}$ V.E. Zuev Institute of Atmospheric Optics SB RAS, Tomsk, Russia; \\ ${ }^{3}$ National Research Tomsk Polytechnic University, Russia \\ (E-mail: denkasymov@gmail.com)
}

\title{
On the design of some devices for localization and extinguishing wildfires of different intensities
}

\begin{abstract}
Topicality of the study of natural fires and techniques to control them is obvious. About 18000 people in the Russian Federation lose annually their lives as a result of forest fires. Analysis is shown that forest fires are particularly frequent in Siberia and the Far East of Russia, where the number of deaths from forest fires up to 10000 people exceeds the same indicator in the European part of Russia by 4-5 times. General situation in the world shows shortcomings in the existing system of monitoring forests and the low efficiency of the methods used to localize and extinguish fires. Development of devices for localizing and extinguishing wildfires of various intensities is considered, based on knowledge of flame structure, including drying, heating, pyrolysis and mixing with atmospheric oxygen zones, which can be affected by relatively low energy disturbances (shock waves) minimizing environment damage. Theoretical and experimental studies show that shock waves lead to increasing pressure in them at the time of interaction with unstable zones, which increases the suppression efficiency further. It is shown that the practical use of considered technological solutions will make it possible to increase the effectiveness and efficiency of measures to suppress wildfires.
\end{abstract}

Keywords: physical and mathematical modeling, natural and technological disasters, combustion suppression, shock wave, ignition, experiment, localization and suppression.

\section{Introduction}

Wildfires occur around the world leading not only to enormous economic costs, but also threaten human health and life, destroy forest vegetation and biomass, which entails significant soil erosion under the influence of water and wind. Experience has proven that the number of disparate sources of fire or largescale fires does not decrease year by year, despite the improvement of forecast systems for forest fire hazard systems [1,2]. Recently, fires have arisen in more remote and wetlands, which complicates the delivery of equipment for their localization. This is partly due to the expansion of human economic activity, which increases the risk of fire, as well as deforestation of available forest resources. The relevance of studying the effects of seat of fire on peatlands and wood is explained by the need for an in-depth understanding of the thermophysical processes that occur during the ignition and burning of peat and wood, as well as the study of the mechanisms of transition of one type of fire to another in order to clarify existing measures to prevent, localize and extinguish wildfires.

At present, the following main methods of dealing with wildfires of various intensities are known and widely used: «overwhelming» the front of the lower wildfire; digging the edge of a wildfire with soil in order to create a mineralized strip; water extinguishing using portable backpack forest sprayers, and using aviation; forest fuel materials annealing; explosive methods [3].

All the listed extinguishing methods from the point of view of the mechanism of influence on wildfire can be divided into three groups: a) physical and mechanical extinguishing; b) chemical suppression; c) localization and extinguishing of a fire using shock waves generated by detonation of explosive and powder [2]. The first group (a) includes methods of «overwhelming» and mashing the edge of the fire with branches of deciduous trees or brooms. These methods are used in case of weak burning and on light weakly grassed soils in the absence of cluttering. At the same time, the width of barrier bands is at least $0.5 \mathrm{~m} \mathrm{[4].}$ Group (b) includes forest fuel materials annealing, that is widely used in practice before the fire front [3, 4]. More effective methods of localization and extinguishing using cord charges (v) type PZV-20 and ASH-1p [3]. A significant drawback of these charges is the low efficiency of using the explosive energy of the explosive, since the main energy is dissipated in the environment during the explosion [3]. Therefore, it is necessary to increase the number of charges for the formation of a supporting mineralized strip, which leads to an increase in material and technical costs and, accordingly, increases the cost of the performed work. 


\section{Experimental}

Issues related to the study of structure of the fire front are considered in [5-10]. It is established that in the front of fire (in flame torch) there are several zones: heating of wildland fuel, drying, pyrolysis, mixing pyrolysis products with oxygen, combustion of gaseous and condensed products. As shown in [6-8, 11-13], the most unstable are the pyrolysis and mixing pyrolysis products with atmospheric oxygen of all listed zones. Accordingly, if one will affect them during firefighting and destroy them, then the burning process will stop. A similar approach to the problem of firefighting wildfires aimed at destroying unstable zones allowing one to formulate requirements for new methods and devices: it should be the safety of firefighters, environmental safety associated with the conservation of natural materials, simplicity, and reliability in the devices design, high efficiency. Knowledge on the flame structure [4] can be used to create devices that allow small energy perturbations to destroy the most vulnerable part of flame - the pyrolysis and mixing zone.

One of these devices is considered in [14]. Focusing can be carried out using nozzles having a different profile, for example, an ellipsoid of revolution.

The technique is implemented in the following manner. In the zone of a forest fire, operator determine its intensity and classify it by the type: weak, moderate-intensity, and strong. Thereafter they assess the height of the flame and, at a fi re-safe distance ahead of the front, install a reference stake on the ground cover (Fig. 1).

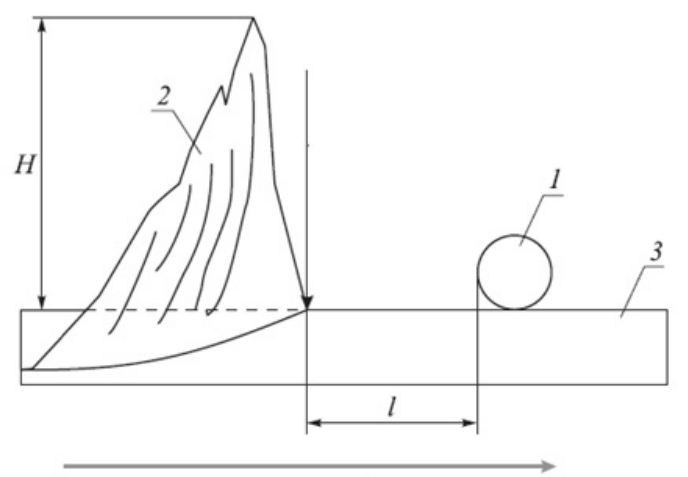

fire front direction

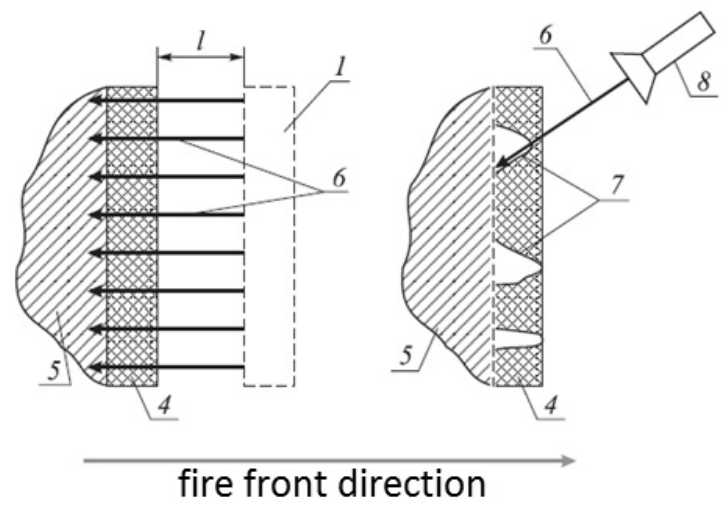

1 - is the explosive charge; 2 - is the flame torch; 3 - is the a cover of natural combustible materials; 4 - is the pyrolysis zone; 5 - is the plot burned natural combustible materials; 6 - is the shock wave; 7 - is the remaining foci of flame; 8 - is the disintegrator

Figure 1. The combined method and scheme of action

A pole with a flag can be used as the reference stake. Then, on the ground cover 3, there is arranged a superimposed pull-cord charge 1 at the distance $\Delta$ from the stake. To eliminate the destruction of the material of the charge container by the action of the thermal wave and to prevent unauthorized detonation of the charge, we determine the distance $\Delta$ from the following relation:

$$
\left(T_{1}-T^{*}\right) /\left(T_{1}-T_{0}\right) \leq \Delta / H \leq\left(T_{1}-T^{*}\right) /\left(T^{\prime}-T_{0}\right),
$$


where $T_{1}$ is the temperature of the flame, $T^{*}$ is the temperature of destruction of the charge container; $T_{0}$ is the environmental temperature, $H$ is the height of the flame, and $T^{\prime}$ is the temperature of the pyrolysis zone.

Once the reference stake is reached by the front's leading edge, the charge is electrically detonated. The detonation of the charge 1 and the explosion of the pyrolysis zone 4 by the shock wave 6 lead to a stall of the flame and a destruction of the fire front. The remaining small combustion sources 7 are extinguished completely using disintegrators 8 .

a
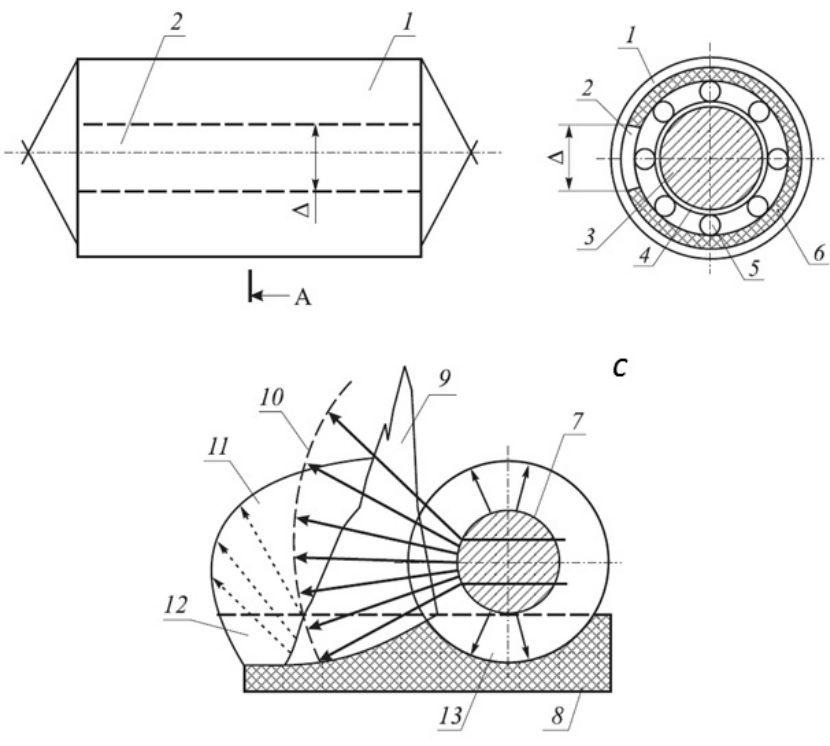

fire front direction

$a$ - is the a general view of an overhead cord charge; $b-$ is the charge design;

$c$ - is the a diagram of action of the explosion products on the front of fire; 1 - is the external elastic shell; 2 - is the groove; 3 - is the explosive cartridge; 4 - is the paper cup; 5 - is the power threads;

6 - is the braid; 7 - is the charge at the time of the explosion; 8 - is the ground cover of natural combustible materials; 9 - is the flame torch; 10 - is the range of the jet; $11-$ is the scope of the shock wave;

12 - is the burned area on the underlying surface; 13 - is the mineralized groove

Figure 2. Overhead cord charge

At the site of the lower forest or steppe fires localization towards the approaching fire front, the proposed cord charge unfolds on the ground cover 8 . It is laid so that groove 2 (Fig. 2) is oriented towards the front of fire. When the front approaches the charge, the latter is detonated by the electric detonator remotely. The gases 7 generated during the explosion of charge create a pressure of hundreds atmospheres [15], as a result of which the structural elements of the charge are destroyed. The outer elastic shell $l$ will collapse first in the region of groove 2 (Fig. 2), the remaining structural elements (Fig. 4) - the braid 6, the power strands 5 , the paper cup 4 is destroyed belatedly. The products of the charge explosion and the resulting shock wave initially rush through the groove 2 . A jet is formed in this case, directed towards the burning center on the underlying surface 8 . The directional action of a shock wave ensures the failure of a flame 9 , and the burning wildland fuel, drying is discharged towards the heated section 12 . The reflected shock wave further enhances the shear of burning natural combustible material. Thereby, the combustion front is destroyed and a mineralized groove 13 is formed.

Knowing the structure of the flame, we can use models of an energy-perturbation source in accordance with the new concept of fighting of forest fires to create devices making it possible to destroy, by energy perturbations, the most vulnerable part of the flame: the zone of pyrolysis and mixing of combustible pyrolysis products with the air oxygen. Focusing of shock waves is known to be used in various fields of science and technology. It is seen that the amplitude of the focused shock wave grows with the length of ellipse $l$ (Fig. 3). 


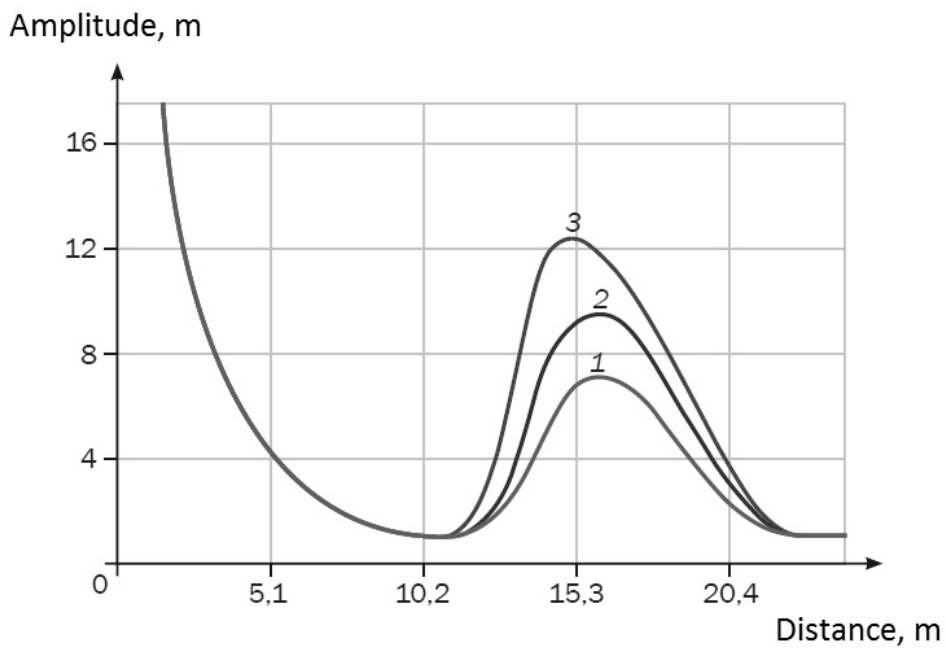

$l_{1}$ - is $6.11 \cdot 10^{-2} \mathrm{~m} ; l_{2}$ is $8.8 \cdot 10^{-2} \mathrm{~m} ; l_{3}$ is $11.44 \cdot 10^{-2} \mathrm{~m}$

Figure 3. Amplitude of the focused shock wave vs. distance to the focusing zone for three versions of a focusing ellipse of various lengths

In accordance with the new concept of firefighting wildfires and knowing the structure of a flame, you can create devices that allow small energy disturbances to destroy the most vulnerable part of a flame - the pyrolysis and mixing zone. One can use the device considered in [16] for these purposes. Focusing of shock waves is known to be used in various fields of science and technology [17-20].

This effect was tested under natural conditions on a proving ground. The device is a modified version of small arms unsuitable to be used for its original function (Fig. 4). A shock wave is formed due to the nozzle. A gunpowder charge 1 is ignited; the formed high-temperature products traverse barrel 2 and enter nozzle 3 . Due to the nozzle shape, an enhanced shock wave forms, which acts on the pyrolysis zone. It should be noted that the exit diameter of the nozzle ranges within $1.8 \cdot 10^{-3}<d_{2}<40 \cdot 10^{-3} \mathrm{~m}$ at the diameter of the critical cross section $3 \cdot 10^{-3}<d_{3}<6 \cdot 10^{-3} \mathrm{~m}$. These values have been selected from the results of the experiments on the proving ground under nearly-actual conditions.

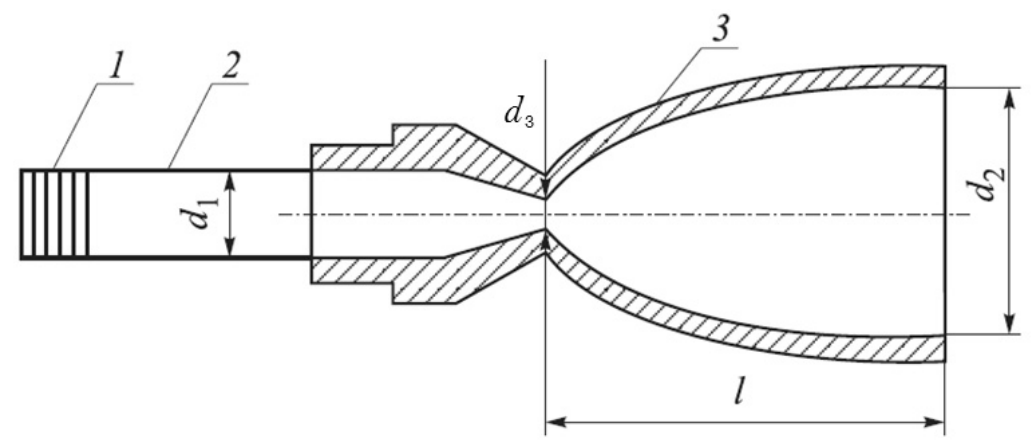

1 - is the gunpowder charge; 2 - is the barrel; 3 - is the nozzles;

$d_{2}$ - is the nozzle inlet diameter; $d_{3}$ - is the nozzle outlet diameter

Figure 4. Device for localization and extinguishing of lower wildfires [12]

\section{Results and its discussion}

An experimental verification of the action of small energy source model disturbances with a focusing nozzle on the front of a lower wildfire is shown in [21]. The experimental results are presented in Table 1. 
Table 1

Field test data [21]

\begin{tabular}{|l|c|c|c|c|c|c|c|}
\hline Type of lower wildfire & Cross-sectional & \multicolumn{2}{|c|}{ Capture depth, [m] } & \multicolumn{2}{c|}{ Capture width, [m] } & \multicolumn{2}{c|}{ Effective range $L,[\mathrm{~m}]$} \\
\cline { 3 - 8 } disintegrator & diameter, $[\mathrm{mm}]$ & $\alpha=30^{\circ}$ & $\alpha=45^{\circ}$ & $\alpha=30^{\circ}$ & $\alpha=45^{\circ}$ & $\alpha=30^{\circ}$ & $\alpha=30^{\circ}$ \\
\hline Cone-type & 5 & 0.75 & 0.55 & 0.4 & 0.4 & 1.2 & 1.2 \\
\hline Parabolic & 5 & 0.8 & 0.6 & 0.55 & 0.45 & 1.2 & 1.2 \\
\hline Parabolic & 3 & 0.5 & 0.35 & 0.3 & 0.3 & 1.2 & 1.0 \\
\hline
\end{tabular}

Three types of nozzles were tested. An analysis of the tests results conducted on the territory of the Timiryazevsky forestry in Tomsk of Tomsk region and in Krasnoyarsk showed that nozzles with a parabolic internal cavity and a diameter of critical section $d_{k}=5 \cdot 10^{-3} \mathrm{~m}$ have better characteristics than cone-shaped with the same critical diameter section or with a parabolic internal cavity, but with a diameter of the critical section $d_{k}=3 \cdot 10^{-3} \mathrm{~m}$. It was determined during the experiment that one person armed with $\mathrm{n}$ a disintegrator extinguishes up to $10 \mathrm{~m}$ of the fire front in 1 minute using 30 rounds. A group of four with ammunition equipped in four magazines (120 rounds) can extinguish up to 160 meters of the front fire in $4 \div 5$ minutes [22].

Table 2 shows the results of measuring the braking pressure of various designs [22].

Table 3 presents spent time estimation, people/min (machine/min), for some work to extinguish a 100meter edge of the lower wildfires [23].

The experiments confirmed the possibility of using this device for extinguishing low and medium intensity lower wildfires.

In addition, as a result of experimental studies of the probability of ignition of plant combustible materials from a lower wildfire [22, 23-24], a knapsack motorized fire extinguisher is proposed as a means of suppression a low-intensity lower wildfire, which structural diagram is shown in Figure 5 [25].

Table 2

The experiment results on measuring the braking pressure of various designs

\begin{tabular}{|l|c|c|c|c|}
\hline \multirow{2}{*}{ Type of nozzle } & \multirow{2}{*}{ Gain ratio } & \multicolumn{3}{c|}{ Pressure measurement values, $\mathrm{P}_{\mathrm{av}}, \mathrm{V} \cdot 10^{3}$} \\
\cline { 3 - 5 } & & $\mathrm{L}=0[\mathrm{~m}]$ & $\mathrm{L}=0.5[\mathrm{~m}]$ & $\mathrm{L}=1[\mathrm{~m}]$ \\
\hline Parabolic $\mathrm{D}_{\text {out }}=36[\mathrm{~mm}]$ & 1.15 & 67 & 49 & 41 \\
\hline Cone-type $\mathrm{D}_{\text {out }}=36[\mathrm{~mm}]$ & 1.09 & 63 & 46 & 39 \\
\hline Ellipsoidal $\mathrm{D}_{\text {out }}=36[\mathrm{~mm}]$ & 1.1 & 64 & 47 & 40 \\
\hline Parabolic $\mathrm{D}_{\text {out }}=36[\mathrm{~mm}]$ & 1.26 & 73 & 54 & 45 \\
\hline Cone-type $\mathrm{D}_{\text {out }}=36[\mathrm{~mm}]$ & 1.25 & 72 & 53 & 45 \\
\hline Without nozzle $\mathrm{D}_{\text {out }}=36[\mathrm{~mm}]$ & - & 58 & 42 & 36 \\
\hline
\end{tabular}

Table 3

Spent time on various extinguishing of the 100-meter edge of the lower wildfires

\begin{tabular}{|l|c|c|}
\hline \multicolumn{1}{|c|}{ Type of work } & \multicolumn{2}{c|}{ Cost } \\
\cline { 2 - 3 } & people/min & machine/min \\
\hline $\begin{array}{l}\text { Laying of a barrier strip 0.5 m wide: } \\
-5 \text { tractor plow brigade }\end{array}$ & $\begin{array}{c}80-100 \\
10-15\end{array}$ & $2-3$ \\
\hline Using a removable fire truck & 6 & 3 \\
\hline Using explosive materials with wells through 1 m & $100-200$ & \\
\hline Chemical solutions 1 m wide & $15-18$ & 15 \\
\hline $\begin{array}{l}\text { While extinguishing the fire edge with two fire jets of water } \\
\text { with processing a strip 10 m wide by a team of 6 people }\end{array}$ & 40 & \\
\hline $\begin{array}{l}\text { Ignition of the cover from the finished support strip } \\
\text { by two teams of 5 people each with a guard }\end{array}$ & $5-10$ & \\
\hline $\begin{array}{l}\text { Extinguishing using the device for localization } \\
\text { and extinguishing of lower wildfires 1 person }\end{array}$ & 10 & \\
\hline $\begin{array}{l}\text { Team (2 people with the device for localization and extinguishing } \\
\text { of lower wildfires and 1 person with a knapsack forest sprayer) }\end{array}$ & $4-5$ & \\
\hline
\end{tabular}


The fire extinguisher is used as follows: before carrying out the work, a firefighter fixes on the back with the help of straps a motorized backpack fire extinguisher and goes to the place of work. Upon arrival, presses the «start» button on the control panel 13 and starts the hydraulic pump 16. Fire extinguishing fluid through the adapter 6 enters the pump 16 and is fed into the pressure hose 8 . The firefighter operator opens the crane 9 , and the extinguishing fluid from the tank 1 through the pipe 12 and the pressure hose 8 is fed to the control panel 10 and rushes through it to the fire. Perforated protective cover eliminates accidental mechanical damage to the control panel.
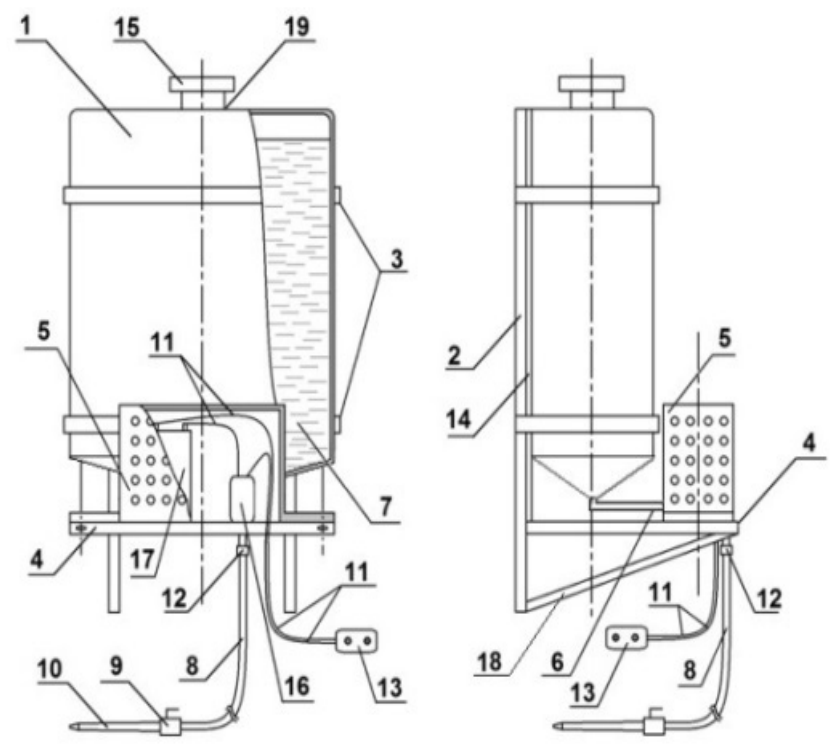

1 - is the capacity for extinguishing fluid; 2 - is the frame support; 3 - is the fixing collars; 4 - is the platform; 5 - is the instrument compartment in a perforated protective casing; 6 - is the capacity adapter;

7 - is the fire extinguishing liquid; 8 - is the pressure head sleeve; 9 - is the crane; $10-$ is the a hydraulic console;

11 - is the electric control cable; 12 - is the output pipe; 13 - is the control panel; 14 - is the a protective wall; 15 - is the cover; 16 - is the hydraulic pump; 17 - is the current source (battery); 18 - is the console; 19 - is the neck

Figure 5. Knapsack motorized fire extinguisher,

The application of proposed technical solution in practice will increase the trouble-free life, improve serviceability, which will more quickly localize and extinguish wildfires.

A device dropped from an aircraft and having a drop-shaped skeleton with the center displaced downward, which is manufactured from an easily destructible material, e.g., paper, is used at almost inaccessible sites of suppression. The ends of the skeleton are hermetically sealed with plugs whose material can be a polymer incombustible material. The skeleton shape and the presence of a stabilizer and of the rounded-off end of the lower plug improves the accuracy of arrival of the device at the combustion zone, whereas the presence of cells ensures a uniform spraying of the seat of fire (Fig. 6).

The operation of the device is as follows: before departure for the site of fi re-fighting work, one installs plug 4 into skeleton 1 and fixes it with binding 3. Pyrocartridge 8 in a water-resistant container 9 and thermal fuse 10 are installed through the channel 11 of the plug 4 . Then one installs plug 6 and fastens it to the skeleton 1 with the binding 3 . Water is poured through entrance 7 into the cavity of the skeleton. In filling the cavity of the skeleton 1 with water, the entrance 7 is shut by a stopper with stabilizer 5. Stiffening ribs 2 prevent the destruction of the material of the skeleton 1 in filling with water and transporting further. Once the device is delivered to the site of work, it is dropped over the combustion source. Since the skeleton 1 is dropshaped, the displacement of the center of gravity ensures orientation of the device along the gravity vector. As the combustion source is approached, a heat flux from it begins to act on the thermal fuse 10 . The thermal fuse comes into action and initiates the pyrocartridge 8. It is detonated, the container 9 is destroyed, and the gases begin to act on the water in the cavity of the skeleton 1 . The skeleton 1 is destroyed due to the increase in the cavity pressure; the shock wave beats the flame off and the water, via the cells formed by the stiffening ribs, rushes to the smoldering source. 

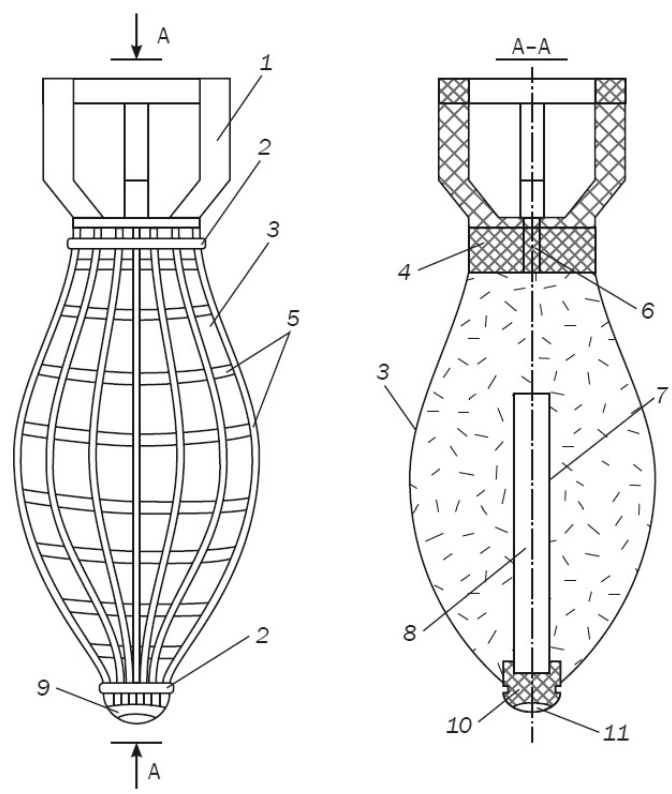

1 - is the skeleton; 2 - is the stiffening ribs; 3 - is the fixing bandages; 4 and 6 - are the plugs;

5 - is the stabilizer; 7 - is the entrance; $8-$ is the pyrocartridge charge; $9-$ is the water-resistant container; 10 - is the thermal fuse; 11 - is the channel

Figure 6. Scheme of the device

Shock-wave generation and water spraying above the source make it possible to considerably increase the suppression area compared to the prototype, which raises the efficiency of action on the combustion source. Furthermore, using the device proposed, one can actively suppress crown forest fires, too.

\section{Conclusion}

The development of localization and extinguishing of upper, lower wildfires and steppe fires is considered in current work. Application and accounting of the presented methods and techniques will improve the efficiency and effectiveness of measures to combat natural and technological disasters.

This approach directed to the destruction of unstable zones allows the new technical methods and devices to be created for providing the safety of fireman-operators, the environmental safety through conservation of natural resources, and the high efficiency. Similar requirements are met by blasting methods: combined method of localization and suppression of ground forest and steppe fires; line charge for localization and suppression of fires, as well as a disintegrator of a ground forest fire front.

This work was carried out with financial support of the Program of Increasing the International Competitiveness of the Tomsk State University for 2013-2020.

\section{References}

1 Grishin A.M. Methods and Devices for Fighting Natural Fires Within a New Concept of Control of Natural and Man-Made Disasters / A.M. Grishin, V.P. Zima, D.P. Kasymov // Journal of Engineering Physics and Thermophysics. — 2014. — Vol. 87. — P. 782-789. doi: 10.1007/s10891-014-1072-7.

2 Johnson E.A. Forest fires: behavior and ecological effects. National Center for Ecological Analysis and Synthesis / E.A. Johnson, K. Miyanishi (Eds.). — Academic Press: Cambridge, Massachusetts, 2001. — 594 p. doi: 10.1016_B978-0123866608 50018-0.

3 Курбатский Н.П. Локализация лесных пожаров накладными шнуровыми зарядами / Н.П. Курбатский, Э.Н. Валендик // Вопросы лесной пирологии. - Красноярск: ИЛиД СО АН СССР, 1970. - С. 320-339.

4 Гришин А.М. Математическое моделирование лесных пожаров и новые методы борьбы с ними / А.М. Гришин. Томск: Изд-во Томск. гос. ун-та, 1997. - 390 с.

5 Mell W.E. The wildland-urban interface fire problem - current approaches and research needs / W.E. Mell, S.L. Manzello, A. Maranghides, D. Butry, R.G. Rehm // International Journal of Wildland Fire. - 2010. - Vol. 19, No. 2. - P. 238-251. doi: 10.1071/WF07131. 
6 Гришин А.М. Об усилении ударных волн при их взаимодействии с фронтом лесного пожара / А.М. Гришин, Ю.М. Ковалев // Докл. АН СССР. — 1990. — Т. 312, № 1. — С. 50-54.

7 Ануфриев И.С. Динамика ударных волн в осесимметричных каналах с конфузорами / И.С. Ануфриев, А.Н. Голованов, А.Ф. Цимбалюк, О.В. Шарыпов // Вестн. НГУ. Сер. Физика. - 2009. — Т. 4, № 2. - C. 13-18.

8 Hevko I. Resonant oscillation of vertical working part of conveyer-loader / I. Hevko, O. Lyashuk, M. Sokil, L. Slobodian, V. Hud, Yu. Vovk // Bulletin of the Karaganda University. Physics series. — 2019. — Vol. 2, No. 94. — P. 73-81.

9 Gulyaev V.I. Focusing and Scattering of Plane Shock Waves at an Interface between Anisotropic Elastic Media / V.I. Gulyaev, G.M. Ivanchenko // Journal of Applied Mechanics and Technical Physics. - 2002. — Vol. 43, No. 5. - P. 654-660. doi: 10.1023/A:1019875400067.

10 Perminov V. Mathematical simulation of the origination and propagation of crown fires in averaged formulation / V. Perminov // Technical Physics. — 2015. — Vol. 60, No. 2. — P. 180-187. DOI: 10.1134/S1063784215020176.

11 Zima V.P. Investigation of the Effect of the Combustion Site on Wood Specimens with the Use of IR Diagnostics / V.P. Zima, D.P. Kasymov // Journal of Engineering Physics and Thermophysics. - 2016. - Vol. 89, No. 2. - P. 466-470. doi: $10.1007 / \mathrm{s} 10891-016-1397-5$

12 Loboda E.L. Modeling of Thermophysical Processes in the Ignition of a Small Wooden Plank / E.L. Loboda, D.P. Kasymov, A.S. Yakimov // Journal of Engineering Physics and Thermophysics. - 2015. — Vol. 88, No. 1. — P. 113-123, doi: 10.1007/s10891-015-1173-y.

13 Гришин А.М. Применение взрывчатых веществ в устройствах локализации и тушения природных пожаров / A.M. Гришин, В.П. Зима, Д.П. Касымов // Пожаровзрывобезопасность. - 2015. - Т. 24, № 7. - C. 52-60. DOI: 10.18322/PVB.2015.24.07.52-60

14 Гришин А.М. Устройства для тушения природных пожаров / А.М. Гришин, В.П. Зима, Д.П. Касымов // Пожары и чрезвычайные ситуации: предотвращение, ликвидация. — 2017. — № 4. - С. 39-45.

15 Орлов Б.В. Термодинамические и баллистические принципы проектирования твердотопливных ракетных двигателей: учеб. для вузов / Б.В. Орлов, Г.Ю. Мазинг. — М.: Машиностроение, 1968. — 536 с.

16 Гришин А.М. Эксплуатация дезинтеграторов при тушении низовых лесных пожаров / А.М. Гришин, В.П. Зима, В.И. Самойлов // Сопряженные задачи механики и экологии: Материалы междунар. конф. — Томск: Изд-во Том. ун-та, 2000. - C. 85-87.

17 Jessen C. Navier-Stokes Simulation and Measurement of Cone Drag at M $\infty=7.9$ / C. Jessen, H. Grönig, M. Watanabe, K. Takayama // Shock Waves @ Marseille I. Berlin. _ Heidelberg: Springer, 1995.

18 Yang J. Shock Wave Propagation and Interactions / J. Yang, Z. Li, Y. Zhu, Z. Zhai, X. Luo, X. Lu // Advances in Mechanics, 2016. - Vol. 46, No. 1. - P. 541-587.

19 Duan Q. Experimental Study of Shock Wave Propagation and its Influence on the Spontaneous Ignition during High-Pressure Hydrogen Release through a Tube / Q. Duan, H. Xiao, L. Gong, P. Li, Q. Zeng, W. Gao, J. Sun // International Journal of Hydrogen Energy. - 2019. - Vol. 44, No. 40. - P. 22598-22607.

20 Takayama K. Visualization of Shock Wave Phenomena / K. Takayama. — Berlin: Springer International Publishing, 2019. doi: 10.1007/978-3-030-19451-2.

21 Woodard P.M. Forest Fire Prevention Data: A Change in Perspectives / P.M. Woodard, J. Niederleitner // The Forestry Chronicle. - 1983. - Vol. 59, No. 5. - P. 229-234.

22 Гришин А.М. Экспериментальные исследования взаимодействия ударной волны, инициированной точечными зарядами, с кронами деревьев / А.М. Гришин, В.П. Зима, А.Л. Мишович, В.И. Самойлов // Сопряженные задачи механики и экологии: материалы Междунар. конф. - Томск: Изд-во Том. ун-та, 2000. — С. 83-85.

23 Makhanov K.M. Noise immunity of radio and mobile communications / K.M. Makhanov, K.T. Ermaganbetov, L.V. Chirkova, A.O. Kasimov, M.A. Maukebayeva, E.T. Arinova, K.M. Turdybekova // Bulletin of the Karaganda University. Physics series. - 2018. - Vol. 4, No. 92. - P. 82-87.

24 Kasymov D.P., Fateev V.N., Zima V.P. Methods and devices used in the wildfire localization for the ptotection of forest ecosystem / D.P. Kasymov, V.N. Fateev, V.P. Zima // Proceedings of the XXIII International Symposium, Atmospheric and Ocean Optics, Atmospheric Physics. — 2017. — Vol. 10466. — P. 1-4. doi: 10.1117/12.2287438.

25 Зима В.П. Ранцевый моторизованный огнетушитель / В.П. Зима, Д.П. Касымов, В.Н. Фатеев // Патент РФ 170469, Бюлл. 12. - 2017.

\section{Д. Касымов, О. Гальцева}

\section{Әр түрлі қарқындылықтағы орман өрттерін оқшаулауға және сөндіруге арналған кейбір құрылғыларды жобалау}

Табиғи өрттерді және оларды қалай жою керектігін зерттеудің өзектілігі маңызды. Ресей Федерациясында орман өрттерінен жыл сайын 18000-ға дейін адам қайтыс болады. Талдау көрсеткендей, Ресейде орман өрттері әсіресе, Сібір мен Қиыр Шығыста жиі кездеседі, мұнда орман өрттерінен қаза тапқандар саны 10000, Ресейдің еуропалық бөлігіндегі көрсеткіштен 4-5 есе асады. Әлемдегі жалпы жағдай орман мониторингінің қолданыстағы жүйесінің кемшіліктерін және табиғи өртті өршітпеу, сөндіру үшін қолданылатын әдістердің тиімділігінің төмендігін көрсетеді. Жалынның құрылымын, оның ішінде кептіру, жылыту, ыдырату, атмосфералық оттегімен араластыру, салыстырмалы түрде аз энергия бұзылыстарына (соққы толқыны) әсер етуі мүмкін, өршітпеу және сөндіруге арналған 
құрылғыларды әзірлеу, келтірілген залалды барынша азайтуға мүмкіндік береді. Теориялық және тәжірибелік зерттеулер көрсеткендей, соққы толқындары тұрақсыз аймақтармен әрекеттескен кезде қысымның жоғарылауына әкеледі, бұл өртті басудың тиімділігін одан әрі арттырады. Қарастырылған технологиялық шешімдерді іс жүзінде қолдану табиғи өрттермен күресудің тиімділігін арттыруға мүмкіндік беретіні көрсетілген.

Кілm сөздер: физикалық-математикалық модельдеу, табиғи және технологиялық апаттар, соққы толқыны, тұтану, эксперимент, өршітпеу және жануды басу.

\title{
Д. Касымов, О. Гальцева
}

\section{О конструкции некоторых устройств для локализации и тушения лесных пожаров различной интенсивности}

\begin{abstract}
Актуальность изучения природных пожаров и способов борьбы с ними очевидна. В Российской Федерации в результате лесных пожаров ежегодно погибает до 18000 человек. Как показывает анализ, в России особенно часто лесные пожары возникают в Сибири и на Дальнем Востоке, где число погибших от лесных пожаров на 10000 человек превышает этот же показатель в европейской части России в 4-5 раз. Общая ситуация в мире показывает недостатки существующей системы мониторинга лесов и низкую эффективность используемых методик локализации и тушения природных пожаров. Рассмотрена методика по устройствам локализации и тушения природных пожаров различной интенсивности, основанных на знании структуры пламени, включая зоны сушки, нагрева, пиролиза, смешения с кислородом воздуха, воздействие на которые возможно относительно малыми энергетическими возмущениями (ударными волнами), что позволяет минимизировать вред, наносимый окружающей среде. Теоретические и экспериментальные исследования показывают, что ударные волны приводят к увеличению давления в них во время взаимодействия с нестабильными зонами, что дополнительно увеличивает эффективность подавления. Показано, что использование на практике рассматриваемых технологических решений даст возможность повысить эффективность и оперативность мероприятий по борьбе с природными пожарами.
\end{abstract}

Ключевые слова: физико-математическое моделирование, природные и техногенные катастрофы, ударная волна, зажигание, эксперимент, локализация и подавление горения.

\section{References}

1 Grishin, A.M., Zima, V.P., \& Kasymov, D.P. (2014). Methods and Devices for Fighting Natural Fires Within a New Concept of Control of Natural and Man-Made Disasters, Journal of Engineering Physics and Thermophysics, 87, 782-789, doi: 10.1007/s10891-014-1072-7.

2 Johnson, E.A., \& Miyanishi, K. (eds.) (2001). Forest fires: behavior and ecological effects. National Center for Ecological Analysis and Synthesis. Cambridge, Massachusetts: Academic Press, doi: 10.1016_B978-012386660-8_50018-0.

3 Kurbatskii, N.P., \& Valendik, E.N. (1970). Lokalizatsiia lesnykh pozharov nakladnymi shnurovymi zariadami [Localization of Forest Fires by Superimposed Pull-Cord Charges]. Krasnoyarsk: ILiD SB AS USSR [in Russian].

4 Grishin, A.M. (1997). Matematicheskoe modelirovanie lesnykh pozharov i novye sposoby borby s nimi [Mathematical modeling forest fire and new methods fighting them]. Tomsk: Publishing House of the Tomsk State University [in Russian].

5 Mell, W.E., Manzello, S.L., Maranghides, A., Butry, D., \& Rehm, R.G. (2010). The wildland-urban interface fire problem current approaches and research needs. International Journal of Wildland Fire, 19(2), 238-251, doi: 10.1071/WF07131.

6 Grishin, A.M., \& Kovalev, Yu.M. (1990). Ob usilenii udarnykh voln pri ikh vzaimodeistvii s frontom lesnoho pozhara [Strengthening of blast waves during interaction with the front of forest fires]. Doklady Akademii nauk SSSR - Reports of the Academy of Sciences of the USSR, 312(1), 50-54 [in Russian].

7 Anufriev, I.S., Golovanov, A.N., Tsimbalyuk, A.F., \& Sharypov, O.V. (2009). Dinamika udarnykh voln v osesimmetrichnykh kanalakh s konfuzorami [Dynamics of shock waves in the cylindrical channel with confusers]. Vestnik NGU. Seriia Fizika - Bulletin of the NSU. Physics Series, 4(2), 13-18 [in Russian].

8 Hevko, I., Lyashuk, O., Sokil, M., Slobodian, L., Hud, V., \& Vovk, Yu. (2019). Resonant oscillation of vertical working part of conveyer-loader. Bulletin of the Karaganda University. Physics Series, 2(94), 73-81, doi: 10.31489/2019Ph2/73-81.

9 Gulyaev, V.I., \& Ivanchenko, G.M. (2002). Focusing and Scattering of Plane Shock Waves at an Interface between Anisotropic Elastic Media. Journal of Applied Mechanics and Technical Physics, 43(5), 654-660, doi: 10.1023/A:1019875400067.

10 Perminov, V. (2015). Mathematical simulation of the origination and propagation of crown fires in averaged formulation. Technical Physics, 60(2), 180-187, doi: 10.1134/S1063784215020176.

11 Zima, V.P., \& Kasymov, D.P. (2016). Investigation of the Effect of the Combustion Site on Wood Specimens with the Use of IR Diagnostics. Journal of Engineering Physics and Thermophysics, 89(2), 466-470, doi: 10.1007/s10891-016-1397-5.

12 Loboda, E.L., Kasymov, D.P. \& Yakimov, A.S. (2015). Modeling of Thermophysical Processes in the Ignition of a Small Wooden Plank. Journal of Engineering Physics and Thermophysics, 88(1), 113-123, doi: 10.1007/s10891-015-1173-y. 
13 Grishin, A.M., Zima, V.P. \& Kasymov, D.P. (2015). Primenenie vzryvchatykh veshchestv v ustroistvakh lokalizatsii i tusheniia prirodnykh pozharov [Using explosive materials in devices of localization and extinguishing of wildland fires]. Pozharovzryvobezopasnost - Fire and Explosion Safety, 24(7), 52-60, DOI: 10.18322/PVB.2015.24.07.52-60 [in Russian].

14 Grishin, A.M., Zima, V.P. \& Kasymov, D.P. (2017). Ustroistva dlia tusheniia prirodnykh pozharov [Devices of extinguishing of wildland fires]. Pozhary i chrezvychainye situatsii: predotvrashchenie, likvidatsiia - Fire and emergencies: prevention, elimination, 4, 39-45 [in Russian].

15 Orlov, B.V., \& Mazing, G.Yu. (1968). Termodinamicheskie i ballisticheskie printsipy proektirovaniia tverdotoplivnykh raketnykh dvihatelei [Thermodynamic and Ballistic Principles of Design of Solid-Propellant Rocket Engines]. Moscow: Mashinostroenie [in Russian].

16 Grishin, A.M., Zima, V.P., \& Samoilov, V.I. (2000). Ekspluatatsiia dezintehratorov pri tushenii nizovykh lesnykh pozharov [Operation of disintegrators in fighting ground forest fires], Proceedings from Conjugate Problems of the Mechanics and Ecology, Mezhdunarodnaia konferentsiia - International Conference. (pp. 85-87). Tomsk: Publishing House of the Tomsk State University [in Russian].

17 Jessen, C., Grönig, H., Watanabe, M., \& Takayama, K. (1995). Navier-Stokes Simulation and Measurement of Cone Drag at $M \infty=7.9$. Shock Waves @ Marseille I. Springer, Berlin, Heidelberg.

18 Yang, J., Li, Z., Zhu, Y., Zhai, Z., Luo, X., \& Lu, X. (2016). Shock Wave Propagation and Interactions. Advances in Mechanics, 46 (1), 541-587, doi: 10.6052/1000-0992-16-009.

19 Duan, Q., Xiao, H., Gong, L., Li, P., Zeng, Q., Gao, W., \& Sun, J. (2019). Experimental Study of Shock Wave Propagation and its Influence on the Spontaneous Ignition during High-Pressure Hydrogen Release through a Tube. International Journal of Hydrogen Energy, 44(40), 22598-22607, doi:10.1016/j.ijhydene.2019.06.166.

20 Takayama, K. (2019). Visualization of Shock Wave Phenomena, Berlin: Springer International Publishing, doi: 10.1007/9783-030-19451-2.

21 Woodard, P.M., \& Niederleitner, J. (1983). Forest Fire Prevention Data: A Change in Perspectives. The Forestry Chronicle, 59(5), 229-234, doi: 10.5558/tfc59229-5.

22 Grishin, A.M., Zima, V.P., Mishovich, A.L., \& Samoilov, V.I. (2000). Eksperimentalnye issledovaniia vzaimodeistviia udarnoi volny, initsiirovannoi tochechnymi zariadami, s kronami derevev [Experimental trial of the disintegrator model on the front of a ground forest fore]. Proceedings from Conjugate Problems of the Mechanics and Ecology, Mezhdunarodnaia konferentsiia International Conference. (pp. 83-85). Tomsk: Publishing House of the Tomsk State University [in Russian].

23 Makhanov, K.M., Ermaganbetov, K.T., Chirkova, L.V., Kasimov, A.O., Maukebayeva, M.A., Arinova, E.T., \& Turdybekova, K.M. (2018). Noise immunity of radio and mobile communications. Bulletin of the Karaganda University. Physics Series, 4(92), 82-87.

24 Kasymov, D.P., Fateev, V.N., \& Zima, V.P. (2017). Methods and devices used in the wildfire localization for the protection of forest ecosystem. Proceedings of the XXIII International Symposium, Atmospheric and Ocean Optics, Atmospheric Physics, 10466, 1-4, doi: 10.1117/12.2287438.

25 Zima, V.P., Kasymov, D.P., \& Fateev, V.N. (2017). Rantsevyi motorizovannyi ohnetushitel [Knapsack motorized fire extinguisher]. RF Patent 170469, Bulletin, 12 [in Russian]. 